\title{
Tebing Tinggi as the Central of Onderafdeeling Padang and Bedagei
}

\author{
Edi Sumarno ${ }^{1}$, Junita Setiana Ginting ${ }^{1}$, Nina Karina ${ }^{1}$, Atika Putri Ananda ${ }^{2}$ \\ ${ }^{1}$ Lecturer in History Study Program, Universitas Sumatera Utara, Indonesia \\ ${ }^{2}$ Alumni of the History of North Sumatra University Study Program \\ edisumarno64@gmail.com
}

\section{Abstract}

Tebing Tinggi was originally an area under the control of the Padang Kingdom. This area had been inhabited since 1864, exactly a year after Jacobus Nienhuys started a tobacco planting business in Deli. As the development of plantation business carried out by Europeans, Tebing Tinggi also experienced changes. In its journey, Tebing Tinggi turned into an area surrounded by plantations. The existence of these plantations makes Tebing Tinggi in the future a role as the center of government for Onderafdeeling Padang and Begadei. What is behind the formation of Onderafdeeling Padang and Bedagei? How was the administration under colonial rule? What is the role of Tebing Tinggi as the center of Onderafdeeling Padang and Bedagei? These questions will be discussed in this paper. This paper uses archival sources and books published during the Dutch colonial administration. This paper aims to describe the history of Onderafdeeling Padang and Bedagei government.
Keywords

Tebing Tinggi; Onderafdeeling Padang and Bedagei; government.

\section{Introduction}

Speaking of regional development in East Sumatera, it cannot be separated from plantations. The success of Jacobus Nienhuys in the experiment of planting Deli Tobacco, which first began in 1863, until finally being able to establish the Deli Maatschappij company in 1869 , became a trigger for other companies to cultivate tobacco as well. Between 1885 and 1886 there were so many contracts for tobacco cultivation. In Langkat, Deli and Serdang areas that year, there was no more land available for tobacco cultivation. Therefore, entrepreneurs direct their businesses in the Padang, Bedagei, Batubara, Asahan, Labuhan Batu, and even Siak regions. ${ }^{1}$ The opening of these plantations is the starting point for change in Padang and Bedagei regions, especially in Tebing Tinggi.

After the opening of plantations around this area, Tebing Tinggi grew from a village into a city. In 1887, according to the Governor General's Besluit dated January 25, 1887 No. 1 / c promulgated in Staatsblad van Nederlandsch Indie No. 21, Tebing Tinggi, by the Dutch East Indies government as the center of Padang Enderage Onderafdeeling as part of the Afdeeling Deli and headed by a controller.

\footnotetext{
${ }^{1}$ W.H.M. Schadee, Geschiedenis van Sumatra's Oostkust deel II, Amsterdam: Oostkust van Sumatera-Instituut, 1919, pp. 181-182.
} 
The population of Tebing Tinggi Sub-District from year to year is always increasing, the increase in population is caused not only by birth but also because the population moved to Tebing Tinggi Sub-District. As of June 2017 the population of Tebing Tinggi Sub-District was 43,075 people consisting of 21,243 men and 22,832 women divided into 11,543 households (HH). (Zuhirayan, 2019)

With the establishment of Tebing Tinggi as the center of onderafdeeling, maka, this region acts as the center of government for the regions below it. Construction of government buildings and various other public facilities began since then.

\section{Research Methods}

The method used in this study is the historical method which includes the heuristic, criticism, interpretation and historiography stages. Heuristics is the process of gathering historical sources related to research topics. The process of gathering these resources was first carried out at the National Archives of the Republic of Indonesia (ANRI). In this place information was obtained from primary sources in the form of handover reports or Memorie van Overgave ( $\mathrm{MvO})$ Controllers for Padang En Bedagei, Staatsblad van Nederlandsch Indie, and also other related archives. The collection of sources was also carried out at the National Library of the Republic of Indonesia, North Sumatera University Library, and Tengku Luckman Sinar Reading Park related to sources relating to research topics in the form of books, theses, journals, and others. After the data is obtained, the next process was to verify the data and then present it in writing.

\section{Discussion}

\subsection{Background of the Establishment of Padang and Bedagei}

The expansion of the plantation business to Padang and Bedagei regions, could be said to be the main cause of the making of these two regions as a driving force. In 1882, before a contract was made for land to be used as plantation land in Padang and Bedagei regions, a committee was formed to conduct an investigation in both regions. The purpose of the investigation was to ensure safety in the opening of the plantation later. The results obtained from this first investigation were that the land issue would be safe if the land was owned by Malays and that the planters would not come into contact with the Batak area. ${ }^{2}$

The next investigation was carried out by Dr. B. Hagen in 1883 . He investigated the Batak region by trying to enter from the upper reaches of Padang-Bedagei into Raya region. However, the threatening attitude of Raya residents forced him to return to Tebing Tinggi and stop his investigation. ${ }^{3}$

Anger of the Raya people increased when in 1885 the King of Padang, namely Tengku Maharaja Muda, was replaced by Sultan Deli's relatives. This is what made the Eastern Batak people in the interior of Padang rebel, because after all the Maharaja Muda was surnamed Saragih too. This rebellion was carried out entirely by order of the Kingdom King, Mr. Rondahaim. Initially, Sultan Deli intended to take up arms, but the Resident of East Sumatera feared this could cause a Batak rebellion against the Dutch. ${ }^{4}$

\footnotetext{
${ }^{2}$ W.H.M. Schadee, op.cit., pp. 181-182.

${ }^{3}$ Ibid.

${ }^{4}$ T. Luckman Sinar, Sumatera Utara Di Bawah Kekuasaan Pemerintah Hindia Belanda (s/d Awal Abad ke XX), Medan: Tanpa Penerbit, Tanpa Tahun Terbit, p. 34.
} 
In 1887, Raya returned to attack in Padang area precisely in Bandar Bejambu Village. This caused damage to several plantations. On October 9, 1887, under the leadership of Captain J.C.R. Schenk, Raya forces were driven out of Bandar Bejambu. But the revolt of the Kingdom did not end just like that. Even in 1888, they again carried out an attack on Baja Linggei. ${ }^{5}$

Given this uncertain situation, it was finally deemed necessary to place a controller in Padang and Bedagei regions. The desire to place a Controller in Padang and Bedagei regions is in line with the wishes of the Dutch East Indies Government. The increase in the plantation industry in fact affected trade and shipping, which also meant an increase in colonial tasks. Therefore, the Dutch East Indies government began to organize the territory of his government and place its officials in these areas. The Dutch East Indies government also viewed the arrangement of this region based on promising prospects in the economic field, namely the expansion of plantation exploitation and in defense of political interests. ${ }^{6}$

Various developments that occurred in East Sumatera, including in Padang Bedagei, eventually led to an overhaul of the administrative area. East Sumatera Residency was divided into more regional units in order to facilitate control of the Dutch Indies Government to remote areas and aim to further strengthen the Indies hegemony over the Malay territory. ${ }^{7}$ Finally in 1887 the resident's original position in Bengkalis was moved to Medan. In addition, based on Staatsblad van Nederlandsch Indie No. 21 of 1887, there was an overhaul of the territorial composition which made Tebing Tinggi act as the center of Onderafdeeling Padang and Bedagei under Afdeeling Deli and was led by a controller. ${ }^{8}$

\subsection{Colonial Government System}

Together with the entry of the Netherlands, there was a change in governance in this region. Similar to other regions under the auspices of the Dutch East Indies Government, in running the government in Onderafdeeling Padang and Bedagei also known as the dualism of government, ${ }^{9}$ Resident, Resident Assistant, including the Controller in a Residency, Afdeeling, and Onderafdeeling run the government bureaucracy without the intervention of the sultan or the local king.

In this case, there was a division of territorial boundaries between the authority of the local king and the authority of the Dutch Indies Government. Apart from territorial division, there was also a classification of the population. Based on Staatsblad van Nederlandsch Indie No. 250a of 1873 stated that Europeans, Chinese and other Foreigners were direct people of the Dutch East Indies Government and therefore their right to judge was taken from the hands of the king, who had been considered that Europeans and their employees were subject to the king's authority. ${ }^{10}$

In carrying out their duties, a controller is assisted by officials who come from the indigenous people, known as demang. Demang himself was also assisted by a assistant in

\footnotetext{
${ }^{5}$ Hubungan dengan Raya baru membaik setelah kematian Tuan Rondahaim pada tahun 1891 dan kedudukannya digantikan oleh putranya yaitu Tuan Kalputakan. W.H.M. Schadee, op.cit., pp. 106-107.

${ }^{6}$ Hendri Dalimunthe, "Terbentuknya Keresidenan Sumatera Timur 1858-1887", in thesis S-2 not published, Medan: Master of History Study Program, Faculty of Cultural Sciences, Universitas Sumatera Utara, 2016, p. 125.

${ }^{7}$ Ibid.

${ }^{8}$ Staatsblad van Nederlandsch Indie No. 21 year 1887.

${ }^{9}$ Hendri Dalimuthe, op.cit., p.103.

${ }^{10}$ Staaatsblad van Nederlandsch Indie No. 250a year 1873.
} 
carrying out his duties. Both Demang and Asisen Demang are employees who are paid by the Dutch Indies Government. ${ }^{11}$

The colonial government which had the most influence on Indonesia was the Netherlands (Pawitro, 2015). In the early 18th century, several parts of Indonesia were occupied by Dutch trading companies (VOC) with their center in Batavia. The influence of Dutch culture is reflected in government buildings which scattered on the island of Java, such as in Madiun (Sukarno et al, 2014) and Kediri (Fajarwati et al., 2011). However, on the island of Sumatra, especially on the East coast, the influence of Dutch arrivals has not been seen as significant (Anderson, 1823). The civilization of society at that time was still very pure and Malay buildings were still used with their original identity. The community governance system was also still managed customarily with the Sultan's authority at several points such as Siak, Deli, Serdang, and Langkat. During that period, there was no acculturation between the Malay local culture and European culture in the eastern coast of Sumatra. Local people already knew a new civilization, but there were also primitive ones. Dutch trading companies had not occupied the East coast region (1822 - 1823) and the plantations had not yet been opened. Malay people still enjoy freedom on their own land with a decent life and have not been disturbed by the presence of the VOC which will later monopolize the trade of agricultural products to the east coast of Sumatra. (Pane, 2019)

The appointment of a demang or assistant demang who came from the indigenous people was so that the colonial government did not go down directly in supervising indigenous communities so that the colonial government did not need to be in direct contact when there was a rebellion among the natives. ${ }^{12}$ To help the controller in supervising the Chinese people, a leader from that group was appointed. In 1887, for the first time a Chinese leader was appointed and stationed at Chalipah Town. It was only in 1890 that the Chinese leader was placed in Tebing Tinggi and in 1892 he was given the title of lieutenant. A Chinese lieutenant in carrying out his duties also assisted by wijkmeester. Wijkmeester is placed in several areas such as in Dolok Merawan, Tanjung Beringin, Rampah, Bandar Kalifah and Dolok Masihul. ${ }^{13}$

\subsection{Public Facilities in Tebing Tinggi for Onderafdeeling Padang and Bedagei}

In 1882 for the first time in Padang the Onderneming Tebing Tinggi Estate was opened. Then in 1883 also opened Onderneming Blidaan and Ramboeng. Until 1891 at Onderafdeeling Padang and Bedagei there were at least 14 plantations and this number continued to grow until 1930 in the handover report of the J.J. controlling position. Mendelaar said there were 142 onderneming in the Padang and Bedagei regions. ${ }^{14}$ So, as a center of onderafdeeling, Tebing Tinggi has a role in providing services for the government area, including also for on -erneming in its territory.

For government administration matters, in Tebing Tinggi there are no buildings that were built specifically to function as a Control Office. From its inception until 1923 in the handover report of the J.F Controller position. Mirandolle mentioned that government of Onderafdeeling Padang and Bedagei rented a building to become a Control Office, the last time it was mentioned in 1923 that the leased building was a building owned by the

\footnotetext{
${ }^{11}$ Muhammad Aziz Rizky Lubis, "Pertanian Karet Rakyat di Tapanuli 1908-1942", in Skripsi S-1, not published, Medan: Department of History, Faculty of Cultural Sciences, Universitas Sumatera Utara, 2016, pp. 18-20.

12 Ibid.

${ }^{13}$ J.J. Mendelaar, Memorie van Overgave van het Bestuur Over de Onderafdeeling Padang Bedagei, Afdeeling Deli Serdang, Residentie Sumatra's Oostkust, 1930, pp. 30-31.

${ }^{14}$ Ibid. pp. 59-60.
} 
Nederlandsch Indische Handelmaatschappij bank with rental fees f. 200 / month. Even though they do not have a controlling office, the services provided by the government can still run well. ${ }^{15}$

In the field of transportation facilities and infrastructure, in 1903 Deli Spoorweg Maatschappij expanded the railway from Perbaungan to Tebing Tinggi. Until 1914 Tebing Tinggi served as the last station. However, in 1915 and 1916 the railway line was extended again to Tanjung Balai and Pematang Siantar. Major changes occurred at Tebing Tinggi along with the expansion of this railroad track. This major change is related to the increasing number of population movements to Tebing Tinggi. ${ }^{16}$ Construction of roads and railways led to traders, officials of the Dutch East Indies Government and others choosing to move to Tebing Tinggi. Related to roads and bridges, construction and repairs have started to be carried out since 1908 and 1909. This is closely related to the preparation of Tebing Tinggi which will be used as a gemeente. The problem of road repairs and maintenance can only be solved until around the 1930s. For bridges, in 1911 an iron bridge over the Padang River was completed. This bridge was originally a bridge made of wood. To ensure that the road to Medan is no longer disturbed, this iron bridge was built. ${ }^{17}$

In the field of health services in 1907, by Hospitaal Vereeniging Padang en Bedagei, a hospital by the name of Centraal Hospitaal Tebing Tinggi was established. In the field of education several schools were established not only in Tebing Tinggi, but also in other areas in the Padang and Bedagei regions. At least in Tebing Tinggi there are seven schools namely Europeesche Lagere School, Hollands Inlandsche School owned by the Dutch East Indies Government, Hollands Inlandsche School founded by Budi Utomo, private school for girls, Vervolgschool, Ambachtschool, and special schools for Chinese people. There are also specialized courses provided for teacher training. ${ }^{18}$

In Tebing Tinggi, there is also an esplanade that functions as a square, sports fields, clean water and electricity networks, markets and abattoirs, as well as other infrastructure built to serve the residents of the city. However, it must be known, some of the infrastructure was built after Tebing Tinggi was designated as a gemeente. Therefore, between public facilities for residents of Onderafdeeling Padang and Bedagei, especially Europeans, and those who settled in Gemeente Tebing Tinggi, cannot be separated.

\section{Conclusion}

The interest in terms of plantation expansion became the main reason for the establishment of Onderafdeeling Padang and Bedagei. In addition, there are also other interests, namely to defend political interests. After the enactment of regulations regarding changes in the composition of administrative areas in East Sumatera based on Staatsblad van Nederlandsch Indie No. 21 of 1887 and the choice of Tebing Tinggi as the center of the onderafdeeling, made it a role in providing services to the area of his administration.

From 1887 until finally Tebing Tinggi had a dual role, namely as the center of Onderafdeeling Padang and Bedagei as well as a Gemeente in 1917, development continued

\footnotetext{
${ }^{15}$ J. F. Mirandolle, Memorie van Overgave van het Bestuur Over de Onderafdeeling Padang Bedagei, Afdeeling Deli Serdang, Residentie Sumatra's Oostkust, 1925, p.12.

${ }^{16}$ This not only happened in Tebing Tinggi, but several other cities such as Medan, Binjai, Lubuk Pakam, and others also experienced the same thing after the road and railroad networks were created. See: Karl. J. Pelzer, Toean Keboen and Farmers: Colonial Politics and Agrarian Struggle, Jakarta: Sinar Harapan, 1985, p. 88.

${ }^{17}$ J.J. Mendelaar, op.cit., pp. 72-73

${ }^{18}$ Atika Putri Ananda, "Gemeente Tebing Tinggi (1917-1942)" dalam Skripsi S-1, not published, Medan: Historical Studies Program Faculty of Cultural Sciences, Universitas Sumatera Utara, 2019, pp. 78-82.
} 
to meet the needs of its inhabitants. Government buildings, schools, roads and bridges, railroad lines, hospitals and others were established in the area. However, the role of Tebing Tinggi as a center of onderafeeling and also gemeente is not well known.

\section{Acknowledgment}

This article couldn't have been possible thanks to funding of "Penelitian DRPM Skema Penelitian Dasar Unggulan Perguruan Tinggi with the contract number 120/UN5.231/ PPM/KP-DRPM/2019. We also thanks to Lembaga Penelitan USU which has accommodated this research. Besides that, we also thanks to Arsip Nasional Republik Indonesia and Perpustakaan Nasional Republik Indonesia because the sources of this article are widely available there.

\section{References}

Ananda, Atika Putri. (2019). “Gemeente Tebing Tinggi (1917-1942)", Skripsi S-1, belum diterbitkan. Medan: Program Studi Ilmu Sejarah Fakultas Ilmu Budaya Universitas Sumatera Utara.

Basarshah II, T. Luckman Sinar. Tanpa Tahun Terbit. Bangun dan Runtuhnya Kerajaan di Sumatera Timur, Medan: Tanpa Penerbit.

Dalimunthe, Hendri. (2016). "Terbentuknya Keresidenan Sumatera Timur 1858-1887, Tesis $S$-2, belum diterbitkan. Medan: Fakultas Ilmu Budaya Universitas Sumatera Utara.

J.F. Mirandolle. (1925).MvO (Memorie van Overgave)van het Bestuur over de Onderafdeeling Padang en Bedagei, Afdeeling Deli Serdang, Residentie Sumatra's Oostkust,25 Juli 1922 - 24 September.

J.J. Mendelaar. (1930). $\mathrm{MvO}$ (Memorie van Overgave) van het Bestuur over de Onderafdeeling Padang Bedagei, Afdeeling Deli Serdang, Residentie Sumatra's Oostkust.

Kerchman. F.W.M. (1930). 25 Jaren Decentralisatie in Nederlandsch Indie 1905-1930. Weltevreden: Vereeniging Voor Locale Belangen.

Lubis, Muhammad Aziz Rizky. (2016). "Pertanian Karet Rakyat di Tapanuli 1908-1942", Skripsi-S1, belum diterbitkan. Medan: Departemen Sejarah Fakultas Ilmu Budaya Universitas Sumatera Utara

Pane, Iman. (2019). The Study of Indisch Architecture Development as an Effort in Preserving the Heritage of Colonial History in Medan. Budapest International Research and Critics Institute (BIRCI-Journal), P. 207-214.

Pelzer,Karl J.(1985). Toean Keboen dan Petani: Politik Kolonial dan Perjuangan Agraria. Jakarta: Sinar Harapan.

Schadee, W.H.M. (1919). Geschiedenis van Sumatra's Oostkust deel II. Amsterdam: Oostkust van Sumatra Instituut.

Sinar, T. Luckman. Tanpa Tahun Terbit. Sumatera Utara Di Bawah Kekuasaan Pemerintah Hindia Belanda s/d Awal Abad ke XX. Medan: Tanpa Penerbit.

Staatsblad van Nederlandsch Indie No. 21 Year 1887

Staatsblad van Nederlandsch Indie No. 250a Year 1873

Zuhirsyan, M. (2019). Implementation of Heritage Distribution in the Community in Islamic Law Antropology Perspective(Study On Simalungun Tribe In Kuta Baru Village, Tebing Tinggi, Serdang Bedagai Regency), Budapest International Research and Critics Institute (BIRCI-Journal), p. 477-486. 